
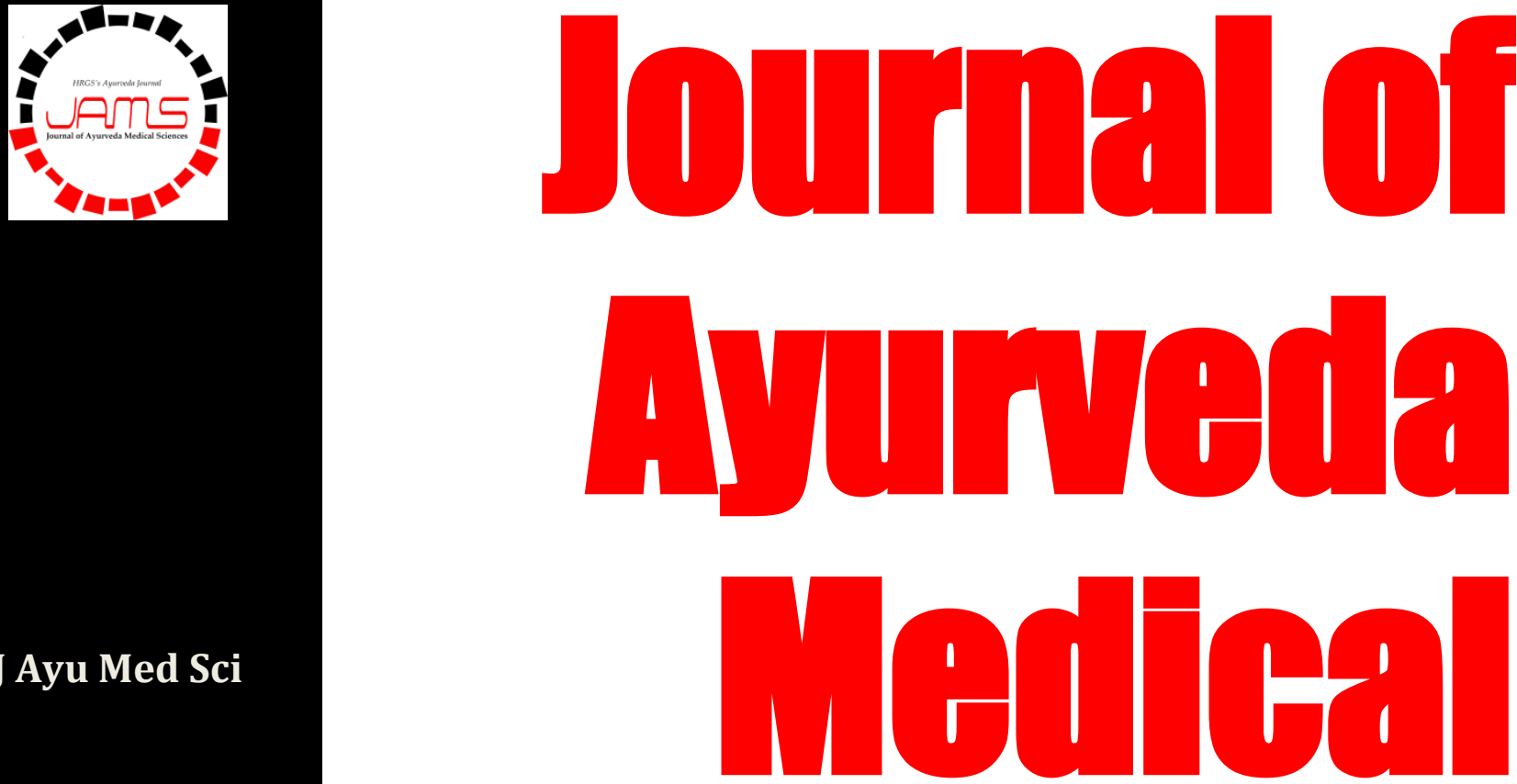

Quarterly Journal for

Rapid Publication

of Researches

in Ayurveda

and Other Traditional

Medicines

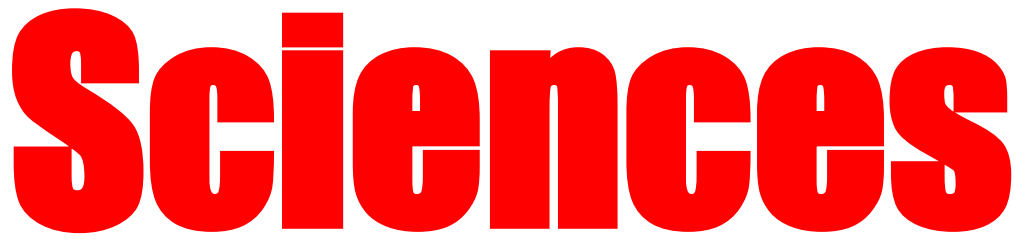

www.jayumedsci.com

ISSN 2456-4990

\title{
Regulatory Perspectives of Preservatives in Ayurvedic Kwatha
}

\section{Formulations}

The classical texts indicate to use the prepared Kwatha within three hours. In present scenario Kwatha are marketed with preservatives as it is highly perishable. The use of preservative is noted to be higher than the recommended ratio. Regulatory bodies insist the pharmaceutical companies to label the name and quantity of preservative which is added to the formulation. Whether in food or pharmaceutical preparation use of right preservative with right amount is necessary to a product's efficacy and safety. There is need to conduct proper study on each Kwatha with preservative separately, as all the formulations are varying in their composition which may ultimately affect the formulations.

Reddy 


\section{Regulatory Perspectives of Preservatives in Ayurvedic Kwatha Formulations}

Seema Mandi Balanga Reddy

Department of Rasashatra and Bhishajya Kalpana, Faculty of Ayurveda, Main Campus, Uttarakhand Ayurved University, Dehradun, 248001, India.

ARTICLE HISTORY Received 25.06.2018 Accepted 17.07.2018

CORRESPONDENCE Email: drseemasdm@gmail.com

CITE THIS OPINION AS Reddy SMB. Regulatory Perspectives of Preservatives in Ayurvedic Kwatha Formulation. J Ayu Med Sci 2018;3(2):344-6.

DOI 10.5530/jams.2018.3.13

In order to recover from disease and achieve healthy status, quality medicines play a pivotal role. The medicine is therefore being given an integral position in triskanda Ayurveda (Hetu, Linga and Oushadi) ${ }^{[1]}$. Herbal drugs can be preserved for longer duration in different dosage forms like powder, tablet, leha (linctus) etc ${ }^{[2]}$. These formulations have less water content and the reduced water activity resists the growth of micro-organisms. Liquid dosage forms cannot be preserved for longer duration because of growth of micro-organisms ${ }^{[3]}$. The maximum shelf life of basic formulations obtained from natural resource like swarasa, kalka and kwatha is 3 hours ${ }^{[4]}$. Among these kwatha (coarse powder meant for decoction) is the most common formulation used in Southern India especially in Kerala. As per the classical reference kwatha has to be consumed in lukewarm state ${ }^{[5]}$ or after it gets cooled on its own ${ }^{[6]}$ depending upon its utility. This is the very situation the role of preservatives come into the formulations. Kwatha is easily prone to microbial attack and addition of preservatives increase the shelf life of the same. Alternative method to preserve kwatha, is to convert it into different dosage forms like ghana vati, kwatha tablets etc. But the pharmacological action of formulations also depends on the dosage forms in which it is used ${ }^{[7]}$. Due to the advent of commercialization longer shelf life has become the need of hour, especially for the preparations like kwatha. Economical as bulk preparations avoided repetition of the procedure, reduce working hours.

The main factor influencing the shelf life of any pharmaceutical product is derivation of the drug, environmental factors like temperature, humidity, light, microbial contamination, different dosage forms, packing material used, storage conditions of the product etc. Antioxidants are added to minimize or retard oxidative processes that occur with some drugs or excipients on exposure to oxygen (air) or in the presence of free radicals. Oxidation of a preparation may be manifested as an unpleasant odor or taste, discoloration or other change in appearance, precipitation, or even a slight loss of activity. These are added to preserve formulations prepared out of ghee and oil.

Preservatives are added to prevent spoilage of pharmaceutical formulations by inhibiting the growth of microorganisms or by other means. Natural/ class I preservative constituents extracted from natural sources eg. salt, sugar, honey etc. Artificial/ class II preservatives are derived from synthetic chemical substance eg. nitrates, benzoates etc ${ }^{[8]}$.

\section{Historical aspects of regulations}

The first legislation, a regulatory prospective was approved in 1848 as "Drug Legislation of the united states of America". In India in 1930 "Drug Enquiry committee" is framed under the chairmanship of Lt. Col. R N Chopra. This committee recommends the formation of "Central Legislation" to set up suitable standards. Later, the drug and cosmetic act was enacted in 1945. In 1964, Ayurveda, Siddha and Unani (ASU) system were supplemented into this act. In the current scenario, Drug and cosmetic acts and rules regulate the production and clinical research.

On forefront Drug and Cosmetic act prevent the addition of allopathic drugs to herbal formulations ${ }^{[9]}$. But the addition of preservative to Ayurvedic formulation is supported by the draft National policy on ISM 2001, under the section 7, stating to adopt modern dosage forms and follow reasonable shelf life period $^{[10]}$. In Consider its Gazette notification stated, Permissible preservatives, Excipients (an inactive substance that serves as the vehicle or medium for a drug or other active substance) for manufacturing ASU formulations (Rule 169) apply to both for Patent and Proprietary ASU Formulations. It also states that no ASU formulation should contain preservatives, excipients, coloring and flavoring agents other than those specified in gazette 
notification. In this notification, total 19 preservatives i.e., 8 Class I preservatives and 11 Class 2 preservatives are stated.

Amendment released in May 2005 was prepared by considering standards under Indian Pharmacopoeia (IP), British Pharmacopoeia (BP), United States National Formulary (USNF), Fruit Product Act (FPA) and Prevention of Food Adulteration (PFA). In this notification the number of preservatives was reduced to 14 .

Gazette released during October 2008 states that, preservatives and coloring agent shall be mentioned clearly on the label and manufactures shall be held responsible to ensure the rationality, safety and quantity of various excipients used in the formulation. The quantity of recipients to be added as prescribed in the authoritative books is specified in the first schedule of the act. The Drug and cosmetic act 1945 part XVII (Rule 161) consist rules of labeling, packing and Limit of alcohol in ASU drugs. But unfortunately, none of the commercial packages we receive contain name and quantity of preservatives added to them.

The presence of preservatives in liquid dosage forms is noted to be higher than the ratio present in food products and many patients complain of Gastric irritations, Nausea and other symptoms. Under Drug and cosmetic rule part XVII- Rule 161-B, Shelf life of different dosage form is mentioned. The Gazette notification released in 2005 for pravahi kwatha (decoction with preservative) is 1 year 6 months. In the continuation of this the Gazette notification released during 2010 states that, the shelf life of pravahi kwatha is 3 years. Even the gazette notification published in 2016 states that the pravahi kwatha can be preserved for 3 years.

\section{Facts and observations}

The recent study conducted on estimation of sodium benzoate in Ayurvedic formulation kashaya (water decoction) ${ }^{[11]}$ shows addition of preservatives, 10 to 15 times more than the internationally accepted level for food. The maximum quantity of intake of paraben salt is $72 \mathrm{mg}$ for $60 \mathrm{~kg}$ of body weight. The study conducted on market sample (X-company preservative ratio) of Nagaradi kwatha with preservative showed that the paraben salt content is $176.01 \mathrm{mg}$ (if $30 \mathrm{ml} /$ day) ${ }^{[12]}$.

Sodium benzoate is commonly used preservative in all the food products. The research work published in 2007 for UK's Food Standards Agency (FSA) states that Ascorbic acid (vitamin C) when used with sodium benzoate forms benzene which is known to be carcinogenic ${ }^{[13]}$.

There is a need of research to study drug and preservative interaction for each Ayurvedic formulation. So before releasing the product to the market, label must be updated by showing all the details of excipients added into the formulation. Addition of preservative in improper manner must be stopped to upgrade Ayurvedic products in the market. Good pharmaceutical preparations are need of the hour.

\section{SOURCE OF SUPPORT Nil}

CONFLICT OF INTEREST This stance is not written to hurt feelings of Ayurveda Pharma sector based on findings in Anonymity. But aimed as eye opener for further course of action to be initiated prior it became an irreversible damage to the society.

\section{REFERENCES}

1. Yadavji Trikamji,editor, ( $1^{\text {st }}$ ed). Caraka Samhita of Agnivesha with the commentary by Cakrapanidatta, Sootra Stana; Dheranjeviteeya Adhaya: Chapter 1, Verse 24. Varanasi: Chaukhamba Surabharati Prakshan, 2016; p.7.

2. Parashuram Shastry Vidyasagar, editor, $\left(1^{\text {st }}\right.$ ed). Sharangadhara Samhita of Sharangadhara with the commentaries of Adhamalla Deepika and Kashiram Gudartha Deepika, Prathama Khanda; Chapter 1, Verse 51-53. Varanasi: Choukamba Orientalia, 2016; p.13.

3. Lopez-Malo, S.M. Alzamora and S. Guerrero, in eds.: S.M. Alzamora, M.S. Tapia and A. Lopez-Malo, Minimally Processed Fruits and Vegetables, Fundamentals Aspects and Applications, Aspen Publishers, Gaithersburg, 2000; p.237.

4. Bramhashanker Shatri, editor, (1 $1^{\text {st } e d) . ~ Y o g a r a t n a k a r a, ~ P u r v a r d h a, ~}$ Jwara Chikitsadhikara, Oushadadhyajeerneannasya Grahyagrahya: Verse 4, Varanasi, Choukamba Prakashan, 2015; p.203.

5. Parashuram Shastry Vidyasagar, editor, $\left(1^{\text {st }}\right.$ ed $)$. Sharangadhara Samhita of Sharangadhara with the commentaries of Adhamalla Deepika and Kashiram Gudartha Deepika, Madhyama Khanda; Chapter 2, Verse 1. Varanasi: Choukamba Orientalia, 2016; p.145.

6. Yadavji Trikamji, editor, $\left(1^{\text {st }}\right.$ ed). Caraka Samhita of Agnivesha with the commentary by Cakrapanidatta, Chikitastana; Jwara Chikitsa: Chapter 3, Verse 239, Chakrapani teeka. Varanasi: Chaukhamba Surabharati Prakshan, 2016; p.420.

7. Yadavji Trikamji, editor, $\left(1^{\text {st }}\right.$ ed). Caraka Samhita of Agnivesha with the commentary by Cakrapanidatta, Sootrastana; Shadveerachanashtasreteeya Adhyaya: Chapter 4, Verse 7, Chakrapani teeka. Varanasi: Chaukhamba Surabharati Prakshan, 2016; p.31.

8. differencebetween.net. Difference Between Class-I Preservative and class-II Preservative; c2018 [cited at 12.09 PM on 30.08.2018] Available from http://www.differencebetween.net/object/comparisons-of-fooditems/difference-between-class-i-preservative-and-class-iipreservative/

9. Gazette of India (Extraordinary) Part II, Section 3, Sub Section (I) in May 2002.

10. Agarwal RK. Proceedings of World Ayurveda Congress, Cochin 2002. 
11. Balachandran S, Sudha Devi R. Estimation of Sodium Benzoate in Ayurvedic Formulation: Kashaya (Water Decoction). Asian Journal of Chemistry 2007;19(5):3421-6.

12. Riya Varghese. Study On The Effect Of Various Concentration Of Preservatives w.s.r. to Nagaradi Kwatha. MD (Ayu) Dissertation, Udupi: SDM College of Ayurveda, 2012.
13. Gardner LK, Lawrence GD. Benzene production from Decarboxylation of Benzoic Acid in the presence of Ascorbic Acid and a Transition- Metal Catalyst. Journal of Agricultural and Food Chemistry. 1993; 41(5): 693-695. 